\title{
Pemberdayaan remaja pesantren melalui biopreneurship pembuatan nugget tempe guna menumbuhkan minat berwirausaha
}

\author{
Adeng Hudaya, Deden Ibnu Aqil *, Zainal Arifin H. Masri \\ Universitas Indraprasta PGRI. Jalan Nangka No. 54, Tanjung Barat, Jakarta Selatan, Indonesia \\ *Corressponding Author. Email: den.aqil@gmail.com
}

Received: 14 August 2019; Revised: 1 December 2019; Accepted: 30 January 2020

\begin{abstract}
Abstrak: Tujuan dari kegiatan ini adalah meningkatkan minat berwirausaha remaja pesantren melalui pemberdayaan dengan biopreunership. Biorpreneurship merupakan suatu pendekatan pemberdayaan yang memadukan anatara konsep-konsep biologi dengan kewirausahaan. Pesantren harus membekali santrinya dengan kemampuan entrepreneurship atau kewirausahan agar mempersiapkan mereka menghadapi kehidupan pasca mereka lulus dari pesantren. Metode yang digunakan dalam kegiatan ini adalah dengan pelatihan membuat keterampilan dalam membuat produk dari bahan hayati atau produk bioteknologi, yaitu tempe dan nugget tempe yang diawali dari pembuatan tempe dilanjutkan dengan pembuatan nugget tempe dari tempe yang telah dibuat. Setelah kegiatan selesai dilakukan pendampingan termasuk evaluasi kegiatan. Hasil dari kegiatan ini berdasarkan hasil uji hipotesis komparatif antara minat berwirausaha sebelum dan sesudah kegiatan dengan Paired Samples Test di dapatkan nilai sig. (2-tailed) adalah $0.008<0.05(\alpha=5 \%)$. Hal tersebut menunjukan bahwa ada pengaruh kegiatan pemberdayaan dengan biopreneurship dalam meningkatkan minat wirausaha remaja pesantren.
\end{abstract}

Kata Kunci: pesantren, biopreneurship, nugget tempe, minat wirausaha.

\section{Empowerment of pesantren adolescents through biopreneurship making nugget tempeto use an interest in enterprises}

\begin{abstract}
The purpose of this activity is to increase the interests of pesantren teenage entrepreneurship through empowerment with biopreunership. Biorpreneurship is an empowerment approach that combines biology concepts with entrepreneurship. Islamic boarding schools must equip their students with the ability of entrepreneurship or entrepreneurship to prepare them for life after they graduate from boarding schools. The method used in this activity is by training to make skills in making products from biological materials or biotechnology products, namely tempeh and tempeh nuggets that begin from making tempeh followed by making tempe nuggets from tempe made. After the activity is completed, there is assistance including the evaluation of activities. The results of this activity are based on the results of the comparative hypothesis test between the interests of entrepreneurship before and after the activity with the Paired Samples Test and the sig. (2-tailed) is $0.008<0.05(\alpha=5 \%)$. This shows that there is an influence of empowerment activities with biopreneurship in increasing the interests of pesantren teenage entrepreneurs.
\end{abstract}

Keywords: pesantren, bioepreneurship, tempe nugget, entrepreneurial interests.

How to Cite: Hudaya, A., Aqil, D., \& Masri, Z. (2020). Pemberdayaan remaja pesantren melalui biopreneurship pembuatan nugget tempe guna menumbuhkan minat berwirausaha. JPPM (Jurnal Pendidikan dan Pemberdayaan Masyarakat), 7(1), 36-44. doi:https://doi.org/10.21831/jppm.v7i1.26667

\section{PENDAHULUAN}

Lulusan sekolah lanjutan tingkat atas (SLTA) merupakan lembaga yang paling tinggi presentasenya dalam hal pengangguran. Sekolah Menengah Kejuruan (SMK) masih mendominasi pengangguran di antara tingkat pendidikan lain, seperti SMA dan Universitas yaitu tercatat sebesar 8,92 \% (SMK), 7,19\% (SMA) dan 7,92 \% (D3) (Badan Pusat Statistik, 2018).

Pada 2030-2040, Indonesia diprediksi akan mengalami bonus demografi, yaitu penduduk dengan usia produktif lebih banyak dibandingkan dengan penduduk non produktif. Di masa ini 
JPPM (Jurnal Pendidikan dan Pemberdayaan Masyarakat), 7 (1), 2020 - 37

Adeng Hudaya, Deden Ibnu Aqil, Zainal Arifin H. Masri

juga diprediksi penduduk usia produktif mencapai $64 \%$ dari total penduduk Indonesia yang diperkirakan mencapai 297 juta jiwa (Afandi, 2017). Oleh sebab itu, banyaknya penduduk dengan usia produktif harus diikuti oleh peningkatan kualitas, baik dari sisi pendidikan, keterampilan, dan semakin ketatnya persaingan di pasar tenaga kerja. Untuk menjawab tantangan tersebut, pemerintah akan fokus pada peningkatan kualitas sumber daya manusia (SDM) melalui pendidikan vokasi yang harus menjadi program prioritas nasional. Hal ini dilakukan dengan penguatan pendidikan vokasi dan peningkatan kompetensi guru. Pendidikan vokasi ini bisa dilaksanakan di semua jenjang pendidikan menengah atas sederajat termasuk pesantren yang juga memiliki lembaga pendidikan formal seperti madrasah aliyah.

Dari situs Kementerian Agama Jawa Barat jumlah pesantren di Kota Depok ada 36 lembaga (https://jabar2.kemenag.go.id) diakses 15 Januari 2015, sedangkan dari dari situs PCNU Depok terdapat 54 lembaga pesantren di Kota Depok dan 15 pesantren berada di Kecamatan Sawangan. Pendidikan pesantren yang menjadi lembaga non formal di Depok ini pula memiliki lembaga pendidikan formal seperti sekolah menengah pertama dan menengah atas.

Menurut Mufti Anam Ketua Dewan Kehormatan HIPMI Banyuwangi (Tribunnews: 2017) "Santri-santri di pesantren harus jadi pelopor. Negeri kita ini masih punya masalah kemiskinan, dan itu harus diselesaikan bersama. Santri-santri harus ambil peran lewat kewirausahaan, sehingga bisa membantu pemerintah mengurangi pengangguran dan kemiskinan. Santri bisa menjadi ujung tombak penguatan ekonomi umat".

Dengan semangat kewirausahaan di pesantren akan memupuk kemandirian siswa dalam menciptakan usaha ketika berada di masyarakat. Tiga langkah dalam menumbuhkan kewirausahaan di pesantren dari artikel surya.co.id. yang Pertama, perubahan paradigma soal kewirausahaan yaitu penanaman paradigma bahwa berwirausaha adalah aktivitas mulia, bukan sekadar mengejar nafsu duniawi semata. Langkah kedua adalah menerapkan kewirausahaan berbasis potensi lokal di sekitar pesantren. Bisnis pesantren ini harus dijalankan SDM lokal pesantren sendiri, menggunakan bahan baku lokal yang mudah dijangkau, dan melibatkan institusi lokal di sekitar pesantren

Langkah ketiga adalah melakukan pemasaran produk dan jasa pesantren secara berkelanjutan. Pesantren mempunyai jejaring luas yang bisa dimanfaatkan sebagai jalur pemasaran. Di antaranya adalah jaringan alumni yang tersebar di seluruh Indonesia. Aspek pemasaran ini termasuk dari sisi kemasan. Diberi sisi marketing yang menarik, misalnya cerita tentang bagaimana produk itu dilahirkan dari pesantren. Manfaatkan pula digital marketing yang jangkauannya luas dan terukur, sehingga produk santri bisa dijangkau lebih banyak konsumen (Haorrahman, 2017).

Masyarakat pesantren umumnya dikenal dengan masyarakat yang tinggal dan menetap di satu tempat, mendapatkan pendidikan agama dengan beragam aktivitas nuansa yang kental dengan keislaman. Ketika santri lulus dari pesantren dan berhadapan dengan masyarakat, mereka akan membawa beragam aktivitas yang telah mereka lakukan selama di pesantren. Kebiasaan-kebiasaan santri di pesantren akan diterapkan dalam kehidupan mereka dirumah, seperti menjadi imam sholat memimpin pengajian, mengajar di sekolah dan aneka kegiatan postitif lainnya. Kegiatan yang diterapkan santri diatas merupakan kegiatan yang biasa dilakukan seorang santri ketika telah di wisuda dari pondoknya.

Pengalaman penulis di pesantren bahwa jarang sekali mendapatkan kegiatan-kegiatan yang dibuat untuk meningkatkan dan mengembangkan keterampiran santri khususnya keterampilan berwirausaha, padahal keterampilan tersebut merupakan keterampilan yang sangat penting untuk hidup di era ekonomi saat ini, dimana jumlah penduduk yang semakin banyak sehingga semakin sulit untuk mendapatkan pekerjaan.

Sulitnya mendapatkan pekerjaan menjadi permasalahan kita semua termasuk pemerintah dalam hal ini dinas tenaga kerja, dimana ketika ada penerimaan tenaga kerja oleh sebuah perusahaan maupun pemerintah selalu melebihi kapasitas penerimaan, bahkan lebih banyak yang tidak mendapatkan kesempatan untuk bekerja. 
JPPM (Jurnal Pendidikan dan Pemberdayaan Masyarakat), 7 (1), 2020 - 38

Adeng Hudaya, Deden Ibnu Aqil, Zainal Arifin H. Masri

Berdasarkan hal tersebut, maka pemberdaayan santri dengan kewirausahaan diperlukan agar dapat memberikan bekal siswa maupun santri dapat berwirausaha tanpa harus mencaricari lapangan pekerjaan. Tujuan dari kegiatan ini adalah membantu meningkatkan minat wirausaha santri di pesantren melalui biopreneurship dengan cara mengolah tempe yang umumnya dimasak dengan digoreng, disayur atau ditumis dalam kegiatan dibuat menjadi nugget.

\section{METODE}

Metode yang digunakan dalam kegiatan pengabdian masyarakat ini adalah kegiatan pelatihan yang melibatkan santri-santri di Pesantren Darus Sholihin di Sawangan Depok sejumlah 25 orang melalui beberapa tahapan sebagai berikut: Pertama, Kegiatan penyadaran tentang pentingnya kewirausahaan sebagai cara meningkatkan ekonomi dengan metode ceramah melalui presentasi dengan menggunakan power point kepada para santri yang mengikuti kegiatan ini. Kedua, Pelatihan membuat keterampilan dalam membuat produk dari bahan hayati atau produk bioteknologi (Habibie, 2011), seperti Tempe dan Nugget Tempe; Ketiga, Pendampingan termasuk evaluasi pelaksanaan kegiatan.

\section{HASIL DAN PEMBAHASAN}

\section{Hasil Kagiatan}

Kegiatan pengabdian masyarakat ini dengan melakukan pemberdayaan dengan pelatihan membuat produk tempe dan setelahnya membuat nugget tempe untuk meningkatkan minat berwirausaha santri. Dengan hasil angket seperti pada Tabel 1.

Tabel 1. Data Hasil Minat Berwirausaha

\begin{tabular}{ccc}
\hline \multirow{2}{*}{ Angket No. } & \multicolumn{2}{c}{ Minat Berwirausaha } \\
\cline { 2 - 3 } & Sebelum & Setelah \\
\hline 1. & 125 & 125 \\
2. & 98 & 125 \\
3. & 105 & 125 \\
4. & 109 & 114 \\
5. & 122 & 145 \\
6. & 129 & 144 \\
7. & 120 & 152 \\
8. & 128 & 130 \\
9. & 110 & 109 \\
10. & 112 & 111 \\
11. & 140 & 117 \\
12. & 120 & 130 \\
13. & 134 & 135 \\
14. & 147 & 130 \\
15. & 124 & 114 \\
16. & 109 & 137 \\
17. & 127 & 133 \\
18. & 128 & 124 \\
19. & 121 & 127 \\
20. & 116 & 123 \\
21. & 113 & 131 \\
22. & 120 & 144 \\
23. & 128 & 152 \\
24. & 110 & 130 \\
25. & 112 & 109 \\
Rata-rata & 120.28 & 128.64 \\
& &
\end{tabular}


JPPM (Jurnal Pendidikan dan Pemberdayaan Masyarakat), 7 (1), 2020 - 39

Adeng Hudaya, Deden Ibnu Aqil, Zainal Arifin H. Masri

\section{Pembahasan}

Dalam kegiatan pemberdayaan ini dilakukan dengan tiga tahapan yaitu (1) pemberian materi tentang penyadaran minat berwirausaha; (2) Pemaparan pembuatan tempe; (3) pembuatan Tempe dan Nugget Tempe.

Pemberian Materi tentang Minat Berwirausaha

Sebelum pelaksanaan proses pembuatan tempe, peserta abdimas dibekali terlebih dahulu dengan ceramah tentang minat berwirausaha dengan materi yang disampaikan adalah meliputi: (1) Kendala dan solusi saat merintis usaha; (2) Trik menyelesaikan masalah tidak memiliki skill; (3) Solusi mengatasi masalah modal; (4) Cara memecahkan problem mencari lokasi usaha; (5) Cara mengurangi ras malas; (6) Cara memulai usaha; (7) Cerita inspiratif orang sukses dengan wirausaha

Pada tahapan pertama ini siswa/i atau santri terlihat antusias dalam mengikuti paparan materi oleh tim pengabdian masyarakat (Gambar 1), hal ini terlihat dari banyaknya siswa/i yang bertanya seputar wirausaha. Paparan materi ini bertujuan untuk memotivasi siswa/i agar minat wirausaha muncul pada diri anak. Berdasarkan pengamatan dilapangan ternyata banyak siswa/i yang termotivasi untuk melakukan wirausaha setelah mendengarkan paparan materi dengan judul menjadi entrepreneur.

Pentingnya penanaman jiwa usaha sejak dini adalah untuk melatih kemandirian anak. Wirausaha bukan hanya dunianya orang dewasa, tapi juga bisa menjadi bagian dari dunianya anak-anak. Bedanya, wirausaha pada anak-anak tak bisa dijalankan sendirian, namun membutuhkan bimbingan dan dukungan dari orang dewasa, orangtua maupun guru. Anak-anak yang mengenal dunia wirausaha sejak dini, akan mendapati manfaat untuk bekal masa depan kelak.

Pada tahapan usia yang masih belia, anak-anak yang belajar menumbuhkan jiwa wirausaha, akan tumbuh menjadi pribadi yang kreatif. Kreativitas yang terlatih sejak dini, termasuk melalui berbagai ajang dan kegiatan kewirausahaan, menjadi modal utama produktivitas dan kemandirian anak kala ia dewasa.

Drucker (2014) mengatakan bahwa "Entrepreneur is one who shifts economic resources out of an area of lower and into an area of higher productivity and greater yield" yaitu bahwa pengusaha adalah salah satu yang bergeser sumber daya ekonomi dari daerah yang lebih rendah dan menjadi wilayah produktivitas yang lebih tinggi dan hasil yang lebih besar (Takdir \& Mahmudin, 2015).

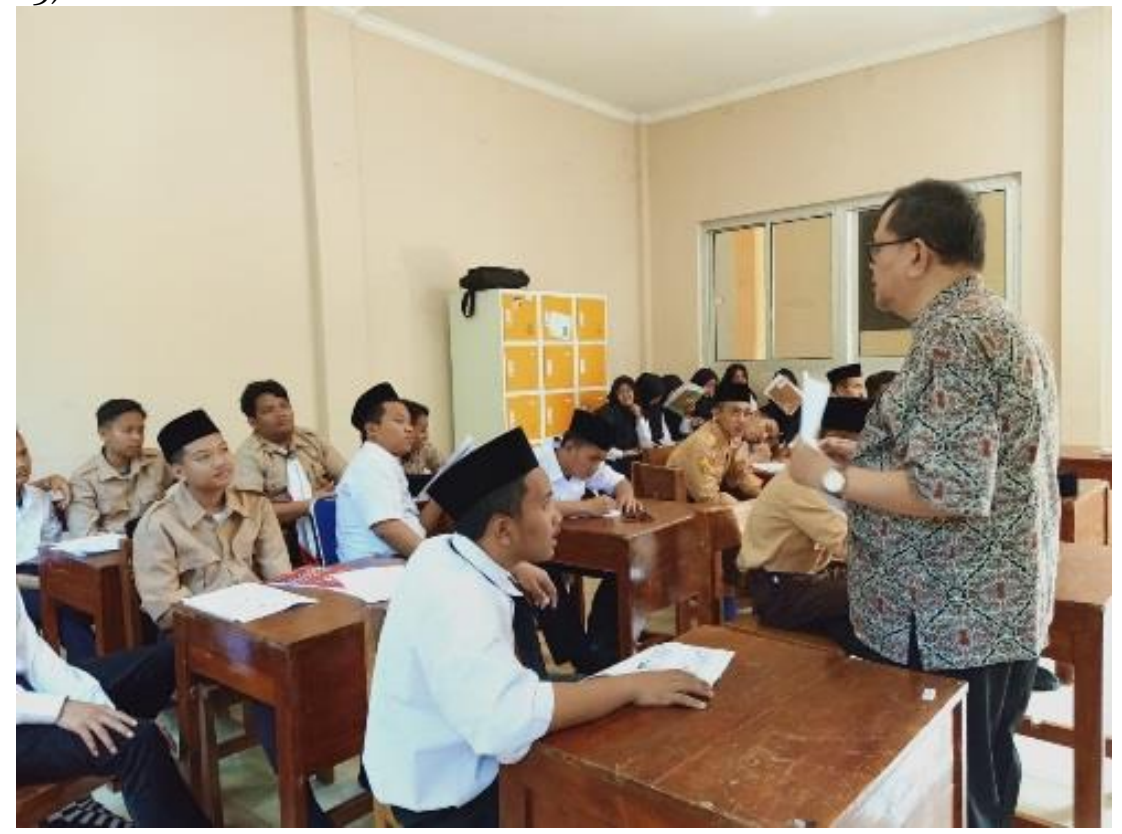

Gambar 1. Pemaparan materi tentang minat wirausaha 
JPPM (Jurnal Pendidikan dan Pemberdayaan Masyarakat), 7 (1), 2020 - 40

Adeng Hudaya, Deden Ibnu Aqil, Zainal Arifin H. Masri

\section{Proses Pembuatan Tempe}

Sebelum proses pembuatan tempe, tim abdimas mencoba menjelaskan materi kepada para santri tentang konsep fermentasi ragi yang digunakan dalam pembuatan tempe serta halhal yang harus diperhatikan dalam peragian dalam membuat tempe.

Proses pembuatan tempe pada siswa/siswi di MA Darusshalihin pertama yang dilakukan adalah mempersiapkan wadah sebagai tempat untuk menampung kacang kedelai yang sudah di fermentasikan sebelumnya, kemudian tempe yang sudah difermentasikan dibersihkan lalu ditiriskan sampai airnya kering. Pada proses selanjutnya adalah dilakukan pengadukan dengan dibubuhi ragi tempe 1 sendok teh untuk $7 \mathrm{Kg}$ tempe. Berikut adalah gambar kegiatan pengadukan kacang kedelai oleh siswa/siswi (Gambar 2).

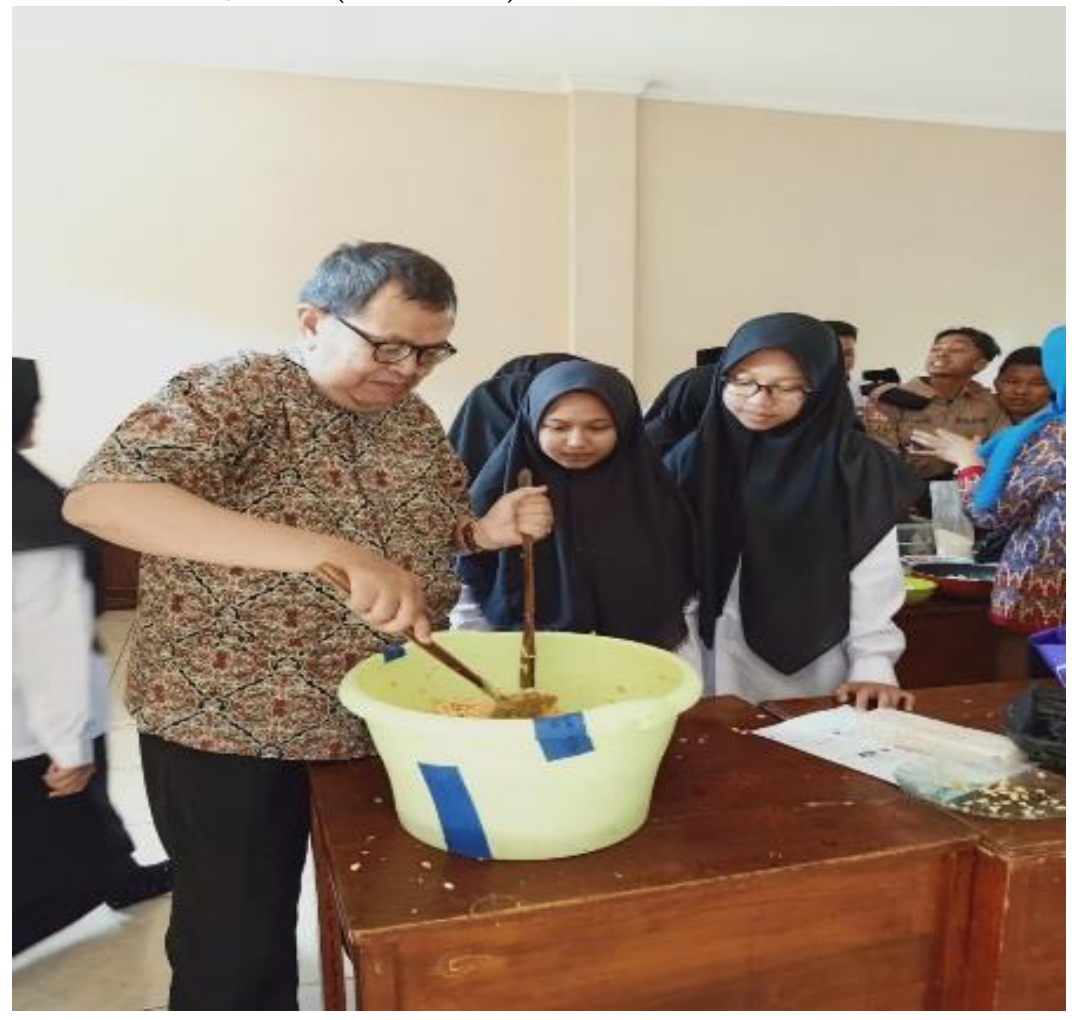

Gambar 2. Proses pengadukan kacang kedelai dengan ragi tempe

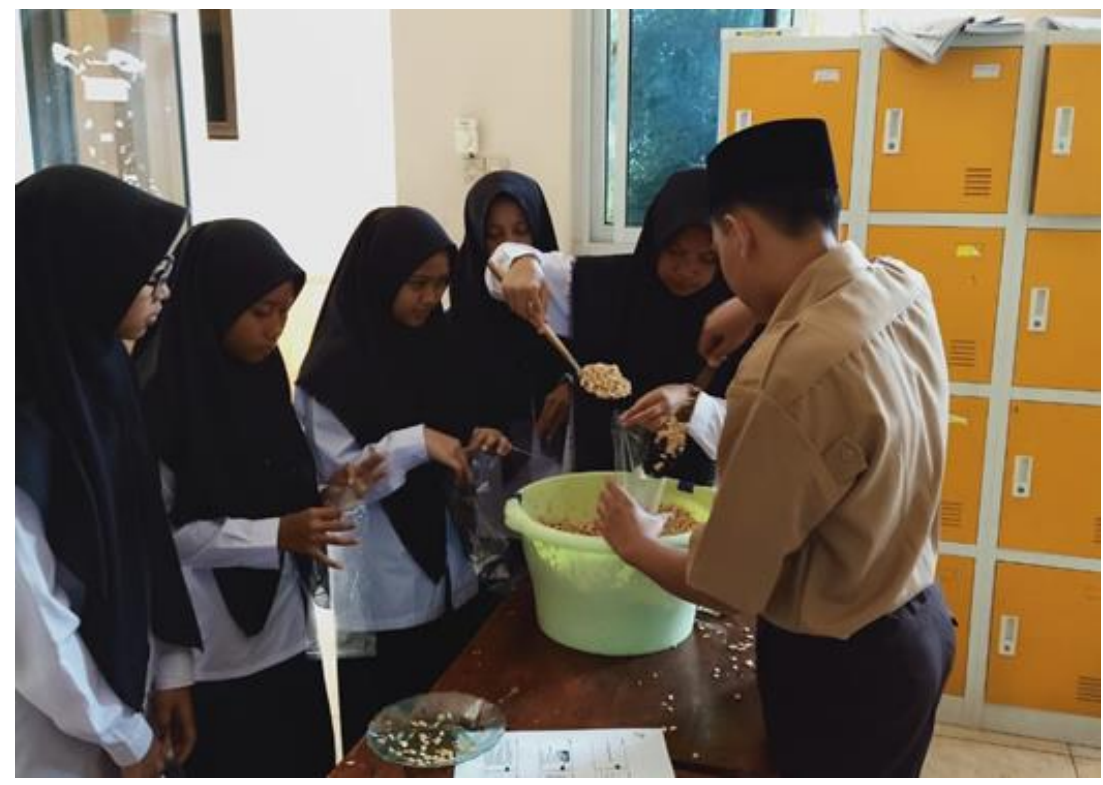

Gambar 3. Proses pembungkusan kacang kedelai 


\section{JPPM (Jurnal Pendidikan dan Pemberdayaan Masyarakat), 7 (1), 2020 - 41}

Adeng Hudaya, Deden Ibnu Aqil, Zainal Arifin H. Masri

Setelah pengadukan selesai dilakukan untuk tahapan selanjutnya dalah proses pembungkusan kacang kedelai ke dalam plastik. Plasitik yang digunakan dalam pembungkusan tempe adalah plastik yang berukuran $1 / 2 \mathrm{Kg}$. banyaknya kacang kedelai yang dimasukkan kedalam kantung plastik adalah sebanyak $2 / 3$ dari jumlah total volume plastik. Hal ini bertujuan untuk memberikan ruang pada kacang kedelai supaya tidak terlalu padat yang akan mengakibatkan pada tempe yang akan dihasilkan. Berikut adalah prose pembungkusan kacang kedelai ke dalam plastik (Gambar 3).

Setelah pembungkusan, dilakukan proses penyimpanan kecang kedelai pada suhu ruang. Ruangan yang digunakan adalah ruang kelas yang tidak digunakan untuk ruang belajar mengajar. Proses penyimpanan ini dilakukan selama 2 × 24 jam atau dua hari. Berikut adalah tempe hasil siswa/siswi setelah proses penyimpanan (Gambar 4 ).

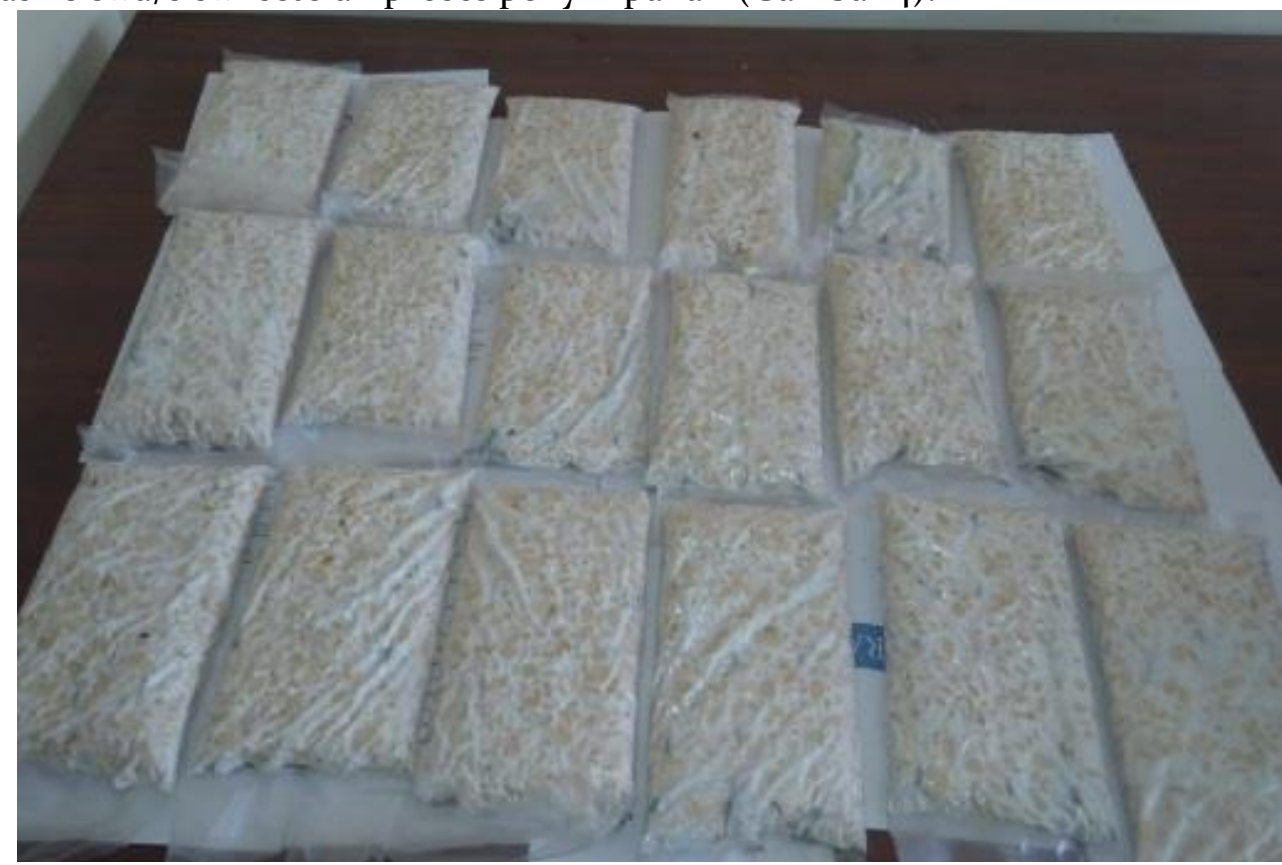

Gambar 4. Tempe setelah proses fermentasi

Disamping kegiatan pengabdian masyarakat yang diikuti oleh siswa/siswi ada beberapa diskusi yang dihasilkan, diantaranya adalah: Pertama, Dalam proses pencucian kacang kedelai yang sudah difermentasikan selama 1 x24 jam harus dicuci bersih, hal ini bertujuan agar tempe yang dihasilkan tidak bau dan rasanya tidak asam. Kedua, pada proses pembubuhan ragi pada kacang kedelai harus memperhatikan kondisi musim yang sedang berlangsung, jika musim panas ragi yang diperlukan untuk kacang kedelai cukup $1 / 2$ takaran, misalnya pada musim panas ragi yang diperlukan untuk $7 \mathrm{~kg}$ kacang adalah 1 sendok teh, sedangkan pada musim penghujan ragi yang diperlukan 1 sendok makan. Ketiga, proses pembungkusan kacang kedelai kedalam plastik harus 2/3 dari jumlah total volume plastik, agar tempe yang dihasilkan dapat mengembang dengan baik. Keempat, plastik yang digunakan harus dilubangi, hal ini bertujuan agar proses fermentasi berlangsung baik sehingga kacang kedelai tidak membusuk.

\section{Proses Pembuatan Nugget tempe}

Setelah proses pembuatan tempe selesai, kagiatan yang dilakukan selanjutnya adalah pembuatan nugget tempe. Nugget tempe merupakan inovasi dari olahan tempe. Bahan yang harus dipersiapkan adalah: tempe, tepung terigu, garam, telur, penyedap rasa, minyak sayur, dan daun bawang. Proses yang pertama adalah tempe dihaluskan, kemudian dicampurkan tepung terigu, ditambahkan telur,daun bawang, lalu ditambahkan semua bumbu secukupnya kemudian dibuat adonan sampai merata. Langkah kedua adalah pembentukan adonan nugget tempe sesuai dengan selera (tergantung cetakan) lalu langkah ketiga adalah proses penggorengan nugget tempe yang sudah dibentuk. Berikut adalah gambar proses pembuatan nugget tempe. 
JPPM (Jurnal Pendidikan dan Pemberdayaan Masyarakat), 7 (1), 2020 - 42

Adeng Hudaya, Deden Ibnu Aqil, Zainal Arifin H. Masri

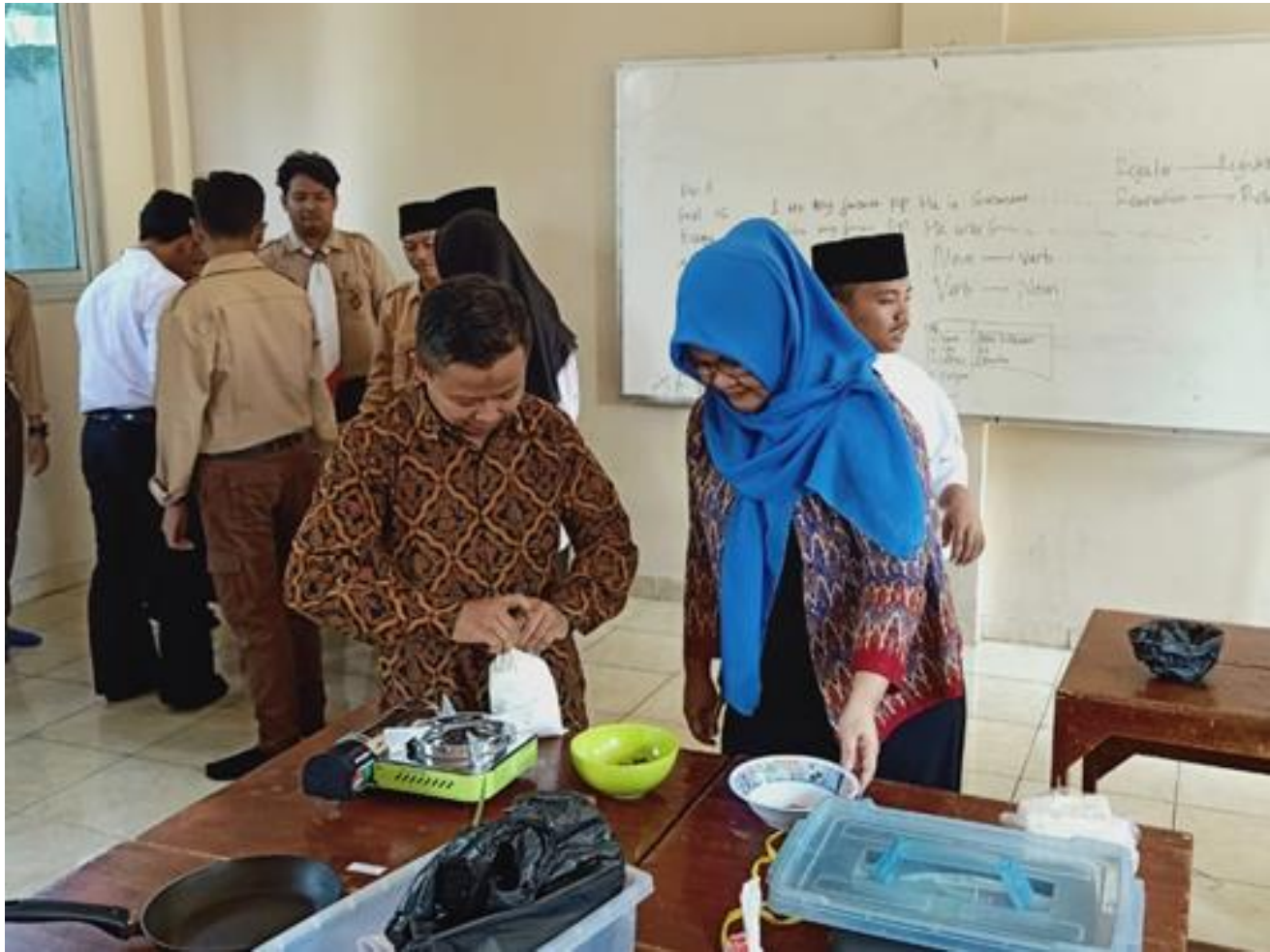

Gambar 5. Proses Pembuatan Nugget tempe

Tujuan tim abdimas memilih membuat nugget tempe adalah adalah agar para santri yang tadinya tidak suka memakan tempe menjadi tertarik untuk memakan tempe. Berdasarkan pengamatan dari kegiatan ini didapatkan bahwa para santri yang menyukai olahan nugget tempe, Berikut adalah gambar proses pembuatan tempe.

Diskusi yang dihasilkan pada saat pembuatan nugget tempe adalah sebagai berikut: Pertama, dalam pembuatan nugget tempe akan lebih baik jika nugget yang sudah dibentuk lalu ditambah dengan tepung panir (tepung roti). Kedua, pada saat proses penggorengan hal yang perlu diperhatikan adalah proses pengapian, api jangan terlalu besar, karena jika terlalu besar nugget tempe tidak akan matang secara merata.

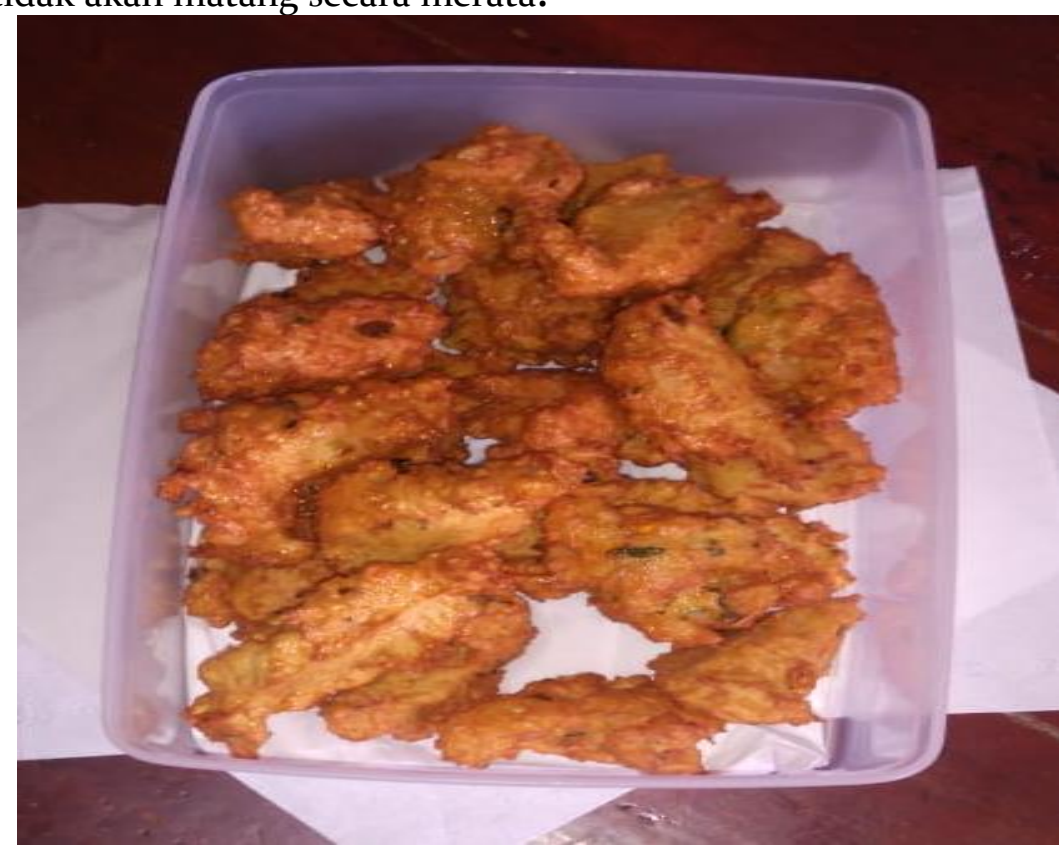

Gambar 6. Nugget tempe yang telah digoreng 
JPPM (Jurnal Pendidikan dan Pemberdayaan Masyarakat), 7 (1), 2020 - 43

Adeng Hudaya, Deden Ibnu Aqil, Zainal Arifin H. Masri

\section{Kegiatan Evaluasi}

Kegiatan evaluasi dalam kegiatan ini adalah dengan menelaah terhadap apa saja yang sudah dilakukan dari awal sampai selesai mulai dari penyajian materi dengan ceramah sampai kepada pembuatan nugget tempe apakah sesuai dengan tahapannya ataukah masih ada kekurangan dan juga kegiatan pendampingan yaitu dengan memberi kesempatan para santri untuk mencoba melakukan pembuatan tempe dan nugget sendiri dibawah pengawasan tim abidmas.

\section{Peningkatan Minat Berwirausaha sebelum dan sesudah penerapan biopreneurship}

Bioenterpreneurship merupakan suatu pendekatan yang memadukan anatara konsepkonsep biologi dengan kewirausahaan. Berdasarkan hasil penelitian diperoleh bahwa biopreneurship mampu memberikann kontribusi yang baik dalam proses pembelajaran atau dalam hal pemberdayaan.

Demikian pula biopreneurship mampu memberikan hasil positif terhadap peningkatan minat berwirausaha siswa/i atau para santri. Dari penelitian ini pada Tabel 1 didapatkan bahwa nilai rata-rata minat berwirausaha terjadi kenaikan dari 120.28 menjadi 128,64 sebelum dan sesudah penerapan metode pembelajaran bioenterpreneurship.

Berdasarkan hasil uji hipotesis komparatif dengan Paired Samples Test di dapatkan nilai sig. (2-tailed) adalah $0.008<0.05(\alpha=5 \%)$. Sehingga dapat disimpulkan bahwa terdapat perbedaan minat berwirausaha sebelum dan sesudah penggunaan metode pembelajaran biopreneurship. Hal tersebut menunjukan bahwa ada pengaruh penggunaan pembelajaran dengan biopreneurship dalam meningkatkan minat wirausaha siswa.

Hasil penelitian Kristanti et al. (2012) menyatakan bahwa berdasarkan pada hasil uji coba lapangan dengan menggunakan pendekatan pemberdayaan dengan pembelajaran biopreneurship menunjukkan bahwa minat kewirausahaan siswa mencapai 91\% dan 94\% pada kelas yang berbeda dan sikap kewirausahaan siswa mencapai $82 \%$ dan 92\%. Berdasarkan hasil tersebut dapat disimpulkan perangkat pembelajaran berbasis bioepreneurship efektif diterapkan dalam kegiatan pembelajaran ataupun dalam kegiatan pemberdayaan serta dapat meningkatkan minat dan sikap kewirausahaan siswa atau santri di pesantren.

Menurut Susanto (2016, pp. 57-58) mengemukakan bahwa minat merupakan kecenderungan jiwa seseorang terhadap suatu objek, dan biasanya kecenderungan jiwa tersebut disertai dengan perasaan senang karena merasa memiliki kepentingan terhadap sesuatu itu yang diminatinya tersebut dan menurut Slameto (2010), minat adalah rasa lebih suka dan rasa ketertarikan pada suatu hal atau aktivitas, tanpa ada yang menyuruh.

Peningkatan minat sebelum dan sesudah pelatihan mengalami peningkatan karena para siswa sebelum kegiatan dilaksanakan belum mengetahui pelatihan apa yang diberikan, namun setelah kegiatan dilaksanakan para siswa mengetahuinya dengan baik, karena minat itu akan muncul ketika seseorang telah mengalami kesuksesan atau keberhasilan dalam mengerjakan sesuatu sedangkan menurut Winkel (2005, p. 212), minat diartikan sebagai kecenderungan subyek yang menetap, untuk tertarik pada bidang studi atau pokok bahasan tertentu dan merasa senang mempelajari materi tersebut.

Hal serupa juga pernah dilakukan oleh Aqil et al. (2019, p. 33) yang menyatakan bahwa kegiatan pembelajaran dengan pendekatan biopreneurship dapat meningkatkan minat berwirausaha dan life skills siswa SMK

\section{SIMPULAN}

Kegiatan pemberdayaan remaja pesantren dengan biopreneurship dapat meningkatkan minat wirausaha santri yaitu dengan melaksanakan kegiatan berupa pelatihan membuat tempe dan produk olahannya berupan nugget tempe dan diperlukan kegiatan lanjutan berupa program untuk analisis usaha nugget tempe. 
JPPM (Jurnal Pendidikan dan Pemberdayaan Masyarakat), 7 (1), 2020 - 44

Adeng Hudaya, Deden Ibnu Aqil, Zainal Arifin H. Masri

\section{DAFTAR PUSTAKA}

Afandi, T. (2017). Bonus demografi 2030-2040: Strategi Indonesia terkait ketenagakerjaan dan pendidikan. Kementerian Perencanaan Pembangunan Nasional/Bappenas. https://www.bappenas.go.id/files/9215/0397/605o/Siaran_Pers_-

_Peer_Learning_and_Knowledge_Sharing_Workshop.pdf

Aqil, D. I., Hudaya, A., \& H. Masri, Z. A. (2019). Peningkatan life skill dan minat wirausaha siswa melalui bio-entrepreneurship (BIOSHIP) SMK di Sawangan Depok. Jurnal Pemberdayaan Masyarakat Madani (JPMM), 3(1), 33-47. https://doi.org/10.21009/JPMM.003.1.03

Badan Pusat Statistik. (2018). Keadaan ketenagakerjaan Indonesia Februari 2018. Bps.Go.Id. https://www.bps.go.id/pressrelease/2018/05/07/1484/februari-2018--tingkatpengangguran-terbuka--tpt--sebesar-5-13-persen--rata-rata-upah-buruh-per-bulansebesar-2-65-juta-rupiah.html

Drucker, P. (2014). Innovation and entrepreneurship. Routledge.

Habibie, A. M. (2011). Resep-resep produk bioteknologi sederhana. Http://Livebiologi.Blogspot.Com/. http://livebiologi.blogspot.com/2011/12/resep-resepproduk-bioteknologi.html

Haorrahman, H. (2017). 3 langkah menumbuhkan kewirausahaan di pesantren ini patut dicoba. Surya.Co.Id. https://surabaya.tribunnews.com/2017/05/13/3-langkah-menumbuhkankewirausahaan-di-pesantren-ini-patut-dicoba

Kristanti, E. A., Bintari, S. H., \& Ridlo, S. (2012). Pengembangan perangkat pembelajaran bioentrepreneurship pembuatan makanan dari limbah cair pengolahan kedelai. Journal of Innovative Science Education, $1(2)$. https://journal.unnes.ac.id/sju/index.php/jise/article/view/633

Slameto. (2010). Belajar dan faktor-faktor yang mempengaruhinya. PT Rineka Cipta.

Susanto, A. (2016). Teori belajar dan pembelajaran di sekolah dasar. Kencana.

Takdir, D., \& Mahmudin, S. Z. (2015). Kewirausahaan. Wijana Mahadi Karya.

Winkel, W. S. (2005). Belajar dan pembelajaran dalam pencapaian prestasi. Sagung. 